\title{
EMOTIONAL TRANSPOSITIONS: INTERPRETING ORAL LYRIC POETRY
}

\author{
Niina Hämäläinen
}

\begin{abstract}
In this article I will discuss perceptions of oral lyric poetry as representations of ideals of emotion. I use the Kanteletar, the most important lyric anthology of nineteenth-century Finland, as an example, asking how oral lyric poetry and its emotions have been represented in written form. In translating oral texts into another, written language, we face a double tension, a fidelity both to oral sources and to the readership for the written transcription. Thus, my interest focuses not only on translation and transference, but also on the interpretative process. The analysis concentrates on one love song from the Kanteletar, in terms of its folk lyric background, and the interpretations made of the song. The song describes emotions, such as love and longing, which are considered to be typical of Romanticism, but are not regarded as very usual among rural people. However, the song has been considered as one of the most beautiful folk songs of love. I will elucidate Lönnrot's editorial technique and demonstrate the multifaceted process involved in the creation and interpretation of the song.
\end{abstract}

Keywords: emotion, interpretation, Kalevala-metre lyric, Kanteletar, love song, textualisation

The Kanteletar, an anthology of oral lyric poetry, is the most important lyric anthology of nineteenth-century Finland. Published in a time period when most of the written literature was in Swedish, the Kanteletar has extensively affected the development of Finnish written poetry and art. Moreover, it has played a crucial role in constructing Finnishness - the ideals of Finnish speakers - and its tradition. The Kanteletar was published in three volumes in 1840 and 1841, and contains 652 lyric songs, ballads, lyro-epic poems, and hymns. Although it also contains men's lyric songs, it has been defined as a book of women's lyric, "a little sister to the Kalevala" (Gröndahl 1997: 33).

Since the publication of the Kanteletar, the diverse and multi-dimensional Kalevala-metre lyric has been ascribed aesthetic and moral attributes. Utilising the special language of people's senses and emotions in the Herderian sense, folk lyric was seen as contrasting with art songs, and was exalted as more valuable in the nineteenth century. It was an expression of emotion, particularly 
of sorrow and worry, and it was regarded as beautifully exhibiting a proper, non-aggressive, non-erotic content in the form of brief lyric (Krohn 1931: 285; Tarkiainen 1943). In Kalevala-metre oral tradition, lyric poetry covers diverse emotional themes, such as sorrow, hatred, humour, eroticism, and the grotesque, but has been labelled as characteristically sorrowful. This side of the lyric has been emphasised by editors such as Elias Lönnrot, and furthermore by readers of the written representations. ${ }^{1}$

"Soitto on suruista tehty, / murehista muovaeltu" ('Music was made of worries, / moulded of sorrows') (Kanteletar I: 1, 9-10). These lines from the first poem of the Kanteletar are considered to represent the essence of oral lyric poetry, its sorrowful voice, even though they were composed by Elias Lönnrot himself (Kaukonen 1984: 43; Laitinen 2003). With this notion as a starting point, I will discuss perceptions of oral lyric poetry as representations of ideals of emotion by using the Kanteletar as an example, asking how oral lyric poetry and its emotions have been represented in written form. Writing down oral tradition, and thus producing the materials for research, poses one of the main epistemological problems in folkloristics. In many European countries, national awakening and its ideological insights along with Romantic ideas of oral song have greatly influenced the methods of collection and publication of oral tradition (Clifford \& Marcus 1986; Bendix 1997; Kuutma 2006.) The knowledge we have about oral culture comes from selected written presentations, their 'written images' produced by educated elite, based on the collected oral material. Collecting, transcribing, translating, interpreting, representing, textualising - every act of transferring oral text into written form is an exercise of power (Kuutma 2006: 15).

In translating oral texts into another, written language, we face a double tension, a fidelity both to oral sources and to the readership for the written transcription. Thus, my interest focuses not only on translation and transference, but also on the interpretative process (see also DuBois 2006). In discussing the mediation of oral tradition to a wider readership in the nineteenth century, which involves the realisation of an interpretation with underlying ideological aims, I refer to the concept of textualisation. Even though oral poetry is always textualised the moment it is heard, transcribed, and made readable, for example by modifying dialectal features, this article highlights the conscious objectives and ideological intentions that are manifested during the process of collecting, editing, interpreting, and publishing folk poems as literary products (as discussed by Bauman \& Briggs 2003). 


\section{THE KANTELETAR IN NINETEENTH-CENTURY FINLAND}

The Kanteletar was completed in a fruitful period of Lönnrot's editorial process. The Kalevala, first published in 1835, had received an excited reception and was celebrated as evidence of Finnish history and language. In the 1830s, Lönnrot undertook long field trips around Karelia, and gathered many lyric songs during the journeys. A first version of the lyric anthology (Alku-Kanteletar (Proto-Kanteletar) 1838) was ready on his work desk, but constantly increasing materials called for a new one. Lönnrot was also thrilled by the lyric songs, in which he daily discovered new beauty (see Lönnrot 1838). As his biographer notes, during field trips Lönnrot developed a good aesthetic sense and his ears came more open to the beauty of the lyric (Anttila 1985 [1931]: 353).

Since its publication, the Kanteletar has enjoyed a valued status as an anthology of oral lyric poetry, and a great number of translations of poems into Swedish were published in newspapers and periodicals right after the anthology had been released. The bourgeois class had a limited knowledge of the Finnish language, most of them not being able to understand folk poems or their messages, but the beauty of the lyric poems was widely acknowledged (ibid.: 261). The reception of the Kanteletar can be described as being one of delight. Despite the general knowledge of Lönnrot's compilation technique of adding in his own verses and combining songs and themes (ibid.: 260-261), the Kanteletar has been defined as an authentic book of oral lyric songs. The songs have been widely celebrated, especially their sorrowful and tender emotions, but not often analysed. ${ }^{2}$

The importance of the Kalevala to readers and scholars is the reason why the role of the Kanteletar in the formation of Finnish culture and heritage has been disregarded and ignored. The Kanteletar has never been subject to such interest or criticism as the Kalevala, which was reviled for being unfaithful to oral sources, for being too complex and long, or for containing genres of poetry that do not belong to epic (e.g. lyric, charms) (see Kaukonen 1956: 425-445; also Gröndahl 1997: 33-34). ${ }^{3}$ There are many kinds of links with oral tradition in the Kanteletar: poems that have little linguistic or thematic resemblance to the oral poetic tradition; poems with resemblances at the linguistic and poetic level; poems that are thematically related to tradition, but have been put into new combinations by Lönnrot.

Lönnrot edited the oral poems for a bourgeois audience unfamiliar with rural culture and its habits, symbols, and meanings. Therefore, he had to modify the oral texts to make them more understandable. His editorial strategies included 
linguistic editing and standardisation of language; complementing a text with lines from variants of the same song; combining different, but usually thematically related, songs, or combining different lines from different sources; creating new songs; extending the length and content of oral songs by adding more parallelism and alliteration than existed in the singing culture. He also aimed to explain the content and meaning of oral songs through diverse textual and contextual changes. ${ }^{4}$ Lönnrot's narrative purposes in the Kanteletar were different from his purposes in the Kalevala. Unlike in the Kalevala, Lönnrot did not link themes and poems to create a narrative entity intended to depict heroes and their deeds as representatives of the Finnish people and their history. However, his ambition in the Kanteletar was to present - based on transcribed song sources and his experience - the narrative of emotionally experienced reality of different folk-poetry genres as widely as it was possible. According to Väinö Kaukonen, songs of the Kanteletar have greatly been generated from the songs Lönnrot himself experienced and transcribed (Kaukonen 1989: 9). Satu Apo (1995a, 1995b) has emphasised the influence of Lönnrot's biography on the collecting and publishing work. Even though my focus in this article is not on the biographical side, it is worth keeping in mind that personal experiences as well as the cultural and historical context of the nineteenth century must have influenced Lönnrot's editorial work (see Karkama 2001).

\section{ORAL LYRIC IN THE PREFACE TO THE KANTELETAR}

The preface of the Kanteletar is one of the few theoretical and interpretative outlines by Elias Lönnrot, and it has been viewed as an important presentation of the essence of folk lyric and its difference from art lyric (Anttila 1985 [1931]: 256; Kaukonen 1984: 13). Lönnrot perceived lyric poetry as a genre, and he made an initial attempt to analyse the emotions of the common people. Lönnrot's notions of the lyric are romantic, but in a wider sense they also reflect perceptions of oral poetry and the lyric as a genre of the nineteenth century. ${ }^{5}$

Lönnrot considered oral lyric poetry as the oldest language to express people's inner feelings. Lauluruno, as he called the lyric song, is composed of mind and thoughts at the moment of singing:

Se maa, joka niitä kasvattaa, on itse mieli ja ajatus, ne siemenet, joista sikiävät, kaikkinaiset mielenvaikutukset. Mutta kun mieli, ajatukset ja mielenvaikutukset kaikkina aikoina ja kaikille ihmisillä enimmiten ovat yhtä laatua, niin runotki, jotka niistä syntyvät, eivät ole yhden eli kahden erityinen omasuus, vaan yhteisiä koko kansalle. (Lönnrot 1993: 320) 
The land that nurtures them [folk poems] is mind and thought itself, those seeds from which all kinds of mental effects are engendered. Yet, just as mind, thoughts and mental impressions are at all times and for all people mostly of one quality, so also the songs that arise from them are not the distinctive characteristic of one or two people, but are common to all people. ${ }^{6}$

Unlike art poetry, the oral lyric is something natural and unpretentious, emerging from one's mind and heart. As the oldest genre of oral poetry, the lyric is also most natural, shared by all people. To emphasise the natural, spontaneous feature of the oral lyric, Lönnrot used metaphors from nature: like clouds that become filled and sprinkle the rain, mind and thoughts sprinkle the words; as the wind churns up waves from the sea, so different mental impressions force them to be sounded (ibid.: 321).

Despite all the changes made in the oral songs, Lönnrot wished to address the truthfulness of his anthology by defining oral lyric as a most sensitive flower, which might get spoiled by the touch of a stranger (ibid.: 353). Lönnrot perceived lyric poetry as another, sacred language that, unlike other oral poems, is able to express one's inner feelings. The beauty of the oral songs grew from their emotions. A sad mind and a song were friends, noted Lönnrot (1990: 407); he regarded loneliness and sadness as characteristic features of the songs of the Kanteletar. In the preface he emphasised that those were Finnish songs, with their origin in the Finnish side of Karelia. Lönnrot himself collected his extensive group of lyric songs from Finnish Karelia and hence the texture of the songs of the Kanteletar is Finnish (Kaukonen 1984: 4-5).

Lönnrot did not pay much attention to singers. For the early collectors like him, the main business was to transcribe as many different songs as possible; singers and their motives for singing were less significant from this point of view (Salminen 1945). The songs were a proof of the collective singing tradition. However, as Lönnrot mentioned, it was mainly old married women that sang lyric songs. Despite the aim of representing diverse oral lyric in the publication that included songs of men and children, Lönnrot emphatically brought together the lyric with female experience. Hard life in the strange home of the husband was the reason to start singing. Fundamentally, melancholic, frustrating experiences, indeed feelings of worry, gave rise to the lyric (see Lönnrot 1990: 406). 


\section{HOW TO INTERPRET AND UNDERSTAND EMOTIONS?}

Multiple selections and publications of the songs of the Kanteletar have been published over the years, but the whole Kanteletar, in its three books, still remains to be translated, even into Swedish (Kukkonen 2009: 94-97; Kaukonen 1984: 1). Lönnrot himself translated songs from the Kanteletar in the 1830s and $1840 \mathrm{~s}$. Swedish translations were published in several periodicals, a total of 45 songs, of which five are from the first book of common songs for everybody, and a great number from the second book of the Kanteletar, songs of girls and women. ${ }^{7}$ Most of the translated songs (34 of the total 45) cover the feelings of loneliness, homelessness, sadness, and frustration: the most widespread feelings in the lyric, as Lönnrot noted. The Kanteletar, "a cloth of worry", as Lönnrot called it, provided an extensive presentation of these themes.

Lönnrot (1838) noticed difficulties in translating the songs into Swedish, saying that many aspects could become lost in translation:

Det är märkvärdigt, att flere stycken af detta lyriska slaget rent af icke kunna öfversättas, och alla förlora sig ganska mycket; ej allenast under min, men äfven under andras skickligare händer.

It is noticeable that many pieces of this lyrical sort are simply impossible to translate, and they all lose a good deal, not just in my hands, but even in the hands of more skilful translators.

When selecting songs and versions for the lyric anthology, Lönnrot followed aesthetic principles with a mind to show presentability, even though he was not always able to keep them:

Toinen huolettavampi asia on se, ettemme aina ole tainneet osata toisintojen seasta sominta ja parasta itse lauluun valita, vaan sen siaan ottaneet jotain kehnompata, vähemmin sopivata. (Lönnrot 1993: 353)

Another matter of greater concern is that we have not always known how to select the most beautiful and best from the mixture of variants for the song, but instead have taken something poorer and less suitable.

The beauty of a lyric song was found not necessarily in the purity of its content but rather in the way of singing and expressing emotion:

Muuten on muistettava, ettei minkään laulun somuus ja kauneus synny aineesta, vaan aineen käyttämästä tahi mielen vapaasta liikunnosta aineita kuvatessansa. (ibid.: 345)

We have to remember that the attractiveness and beauty of any song does not arise from its material, but from the use of the material or the free movement of the mind when making images of the materials. 
Research on emotions emphasises that emotions are physical, and, principally, while emotional complexity is universally shared, emotional language and expressions are nonetheless culturally related (Lutz \& White 1986; Korhonen 2005: 58-59). In elucidating the emotional language of northern Karelian lyric, Senni Timonen has analysed repetitive themes of emotional language. She defines both individual experience and definitional (emic) and cultural (etic) concepts of emotions, emphasising the effects and power of emotional language in different singing contexts as well as in people's relationships (Timonen 2004: 66-67, 309-310). The problem with emotions is their inaccessibility, as well as the difficulties in translating emotional expressions (Timonen 2004: 309; see also Korhonen 2005).

As many scholars have addressed, the meaning in performance is formed from the knowledge shared between the singer and the audience. Thomas DuBois calls it "generic expectations" (DuBois 2006), whereas John Miles Foley uses the term "traditional referentiality" (Foley 1991). Focusing on a receptionalistic view of folk lyric, DuBois describes three typologies of interpretative strategies in analysing the lyric: the generic, the associative (e.g. personalisation), and the situational, of which generic strategy foregrounds the meanings of lyric songs. It consists of the knowledge of what the lyric is, what kinds of themes it contains, how it is performed, and how to interpret it (DuBois 2006: 2-3). How is the generic strategy, the common, shared knowledge, utilised and developed in written publications? Is it possible to reach traditional references without the same culture or language, in a situation where oral songs are published in written form for an audience unfamiliar with its metonymic language, and the cultural meanings it carries?

How are the emotions of oral lyric to be captured when it is not even possible to experience the moment of singing? As transcription lacked modern facilities, and songs were often written down in a hurry, in unreliable situations, on the move (e.g. in a boat) or after the actual time of performance, the preserved oral texts are shifted several stages away from their original performative setting (see DuBois 1994: 141-142; Kaukonen 1984: 39). For collectors and editors of the oral tradition, the generic expectations helped to shape diverse songs the very moment of transcribing or rewriting, but the other strategies, the associative and the situational, might not have been clearly stated (see DuBois 2006: 17). One can also ask what the options were for transmitting emotions. What kind of problems related to emotional aspects did collectors and singers come across in transcription situations? Educated collectors had a cultural and social bridge to cross. Moreover, as men (usually), they may have faced challenges, if not difficulties, in understanding and interpreting the female emotions of the lyric, and its emotional words and meanings. ${ }^{8}$ 
In written presentations made from the oral poetic material, and in interpretations and analyses of the published presentations, problems with transferring and expressing emotions are even more complex. To be able to represent lyric songs in a written form to a modern readership, to preserve a faithfulness to oral sources, an editor has to narrow the gap between two worlds, for example, by reducing the traditional content and the messages of the songs, avoiding improper songs and bringing the oral song to the level where it is comprehensible, but also socially, thematically, and emotionally adequate for the reader. As Elias Lönnrot extended the texture and poetic messages of oral songs, he also modified emotions. He excluded certain emotional themes (the erotic, the aggressive) from the Kanteletar and justified emotions and their expressions to make them understandable and decent. Despite Lönnrot's changes and exclusions of non-proper songs, the Kanteletar, however, as Satu Apo has claimed, includes many aggressive and erotic themes, and can be defined as a realistic depiction of common people (Apo 1995a: 76, 87).

In dissolving meanings and links related to the textualisation process, Richard Bauman and Charles Briggs use a concept of metadiscursive practices that refer to diverse meta-textual usages, which enable oral text to become readable and comprehensible to readers with a limited knowledge of oral tradition. The practices can include, for example, direct discourse and quotation, or use of other genres included in the edited text (Bauman \& Briggs 2003: 208-211). In the case of Lönnrot, according to my tentative analysis, this means adding more parallelism than existed in oral songs, emphasising the lyrical ' $\mathrm{I}$ ' as an experiencing subject of the song, and adding explanatory lines to convey the emotional message of the songs to the modern readership (Hämäläinen 2014). A fundamental set of metadiscursive practices for creating, representing, and interpreting the oral tradition of marginalised groups was developed largely through the lens of Romantic nationalism and scientific perspectives in the first half of the nineteenth century. Metadiscursive practices are, therefore, oriented towards utilising the effects of discursive power and of guiding reception (Briggs 1993: 389-390).

I will next take a look at one love song from the Kanteletar, in terms of its folk lyric background and the interpretations made of the song. The song describes emotions, such as love and longing, which are considered to be typical of Romanticism, but are not regarded as very usual among rural people. However, the song has been considered as one of the most beautiful folk songs of love. By concentrating on this one fairly short example, I aim to elucidate Lönnrot's editorial technique and to demonstrate the multifaceted process involved in the interpretation of the song. 


\section{A SONG OF LOVE}

In the first part of the anthology, Lönnrot placed some love songs under the title of Paimenlauluja ('Herdsman's songs'), which could be sung by both men and women. One of the songs is the well-known love song Armahan kulku ('The beloved's walk'):

This way my treasure has walked, Here my beloved has been,

This way my dear one has stepped, And my white one has wandered; Here she has stepped in the glade, There she has sat on a rock.

The rock is much brighter, The boulder better than the next, The heath twice more fair, And the grove five times sweeter, The wild six times more flowery, All the forest more pleasant, Because that treasure of mine walked, That dear one of mine stepped.

(Bosley 1990: 26-27)
Täst' on kulta kulkenunna, Täst' on mennyt mielitietty,

Tästä armas astununna, Valkia vaeltanunna;

Täss' on astunut aholla, Tuoss' on istunut kivellä. Kivi on paljo kirkkahampi, Paasi toistansa parempi, Kangas kahta kaunihimpi, Lehto viittä leppiämpi, Korpi kuutta kukkahampi, Koko metsä mieluisampi, Tuon on kultani kulusta, Armahani astunnasta. (Kanteletar I: 174)

The fictional subject of the song, I, describes the beloved, the dear one; how the beloved has walked here. Nature has changed to be more beautiful and attractive because of the lover's passage. The poem has been regarded as one of the most beautiful and representative songs of love in the Kanteletar, even though Lönnrot's part in the compilation was recognised (Krohn 1920: 51; Tarkiainen 1921: 104; Kaukonen 1984: 228). ${ }^{9}$ The most celebrated Finnish national composer, Jean Sibelius, composed Rakastava ('The lover') on the basis of this poem; the composition has since popularised the song.

Love lyric is not the most representative theme in the Kalevala-metre lyric poetry. Scholars have tended to see the poems of love as representing longing for love rather than an erotic or passionate feeling (Enäjärvi-Haavio 1935: 131; Tarkiainen 1943; Haavio 1952). This has been explained as a derivation from the norms of old rural culture, and the Lutheran ideals that regarded open sexuality and explicit expressions of emotions as embarrassing (Apo 1989: 168-169). The invisibility of emotions may also reflect the realities of collection: erotic, sensitive feelings were not necessarily presented to strangers, people coming from outside the rural culture. However, as Lönnrot and his contemporaries 
also managed to record, for example, sexual songs, expressing erotic feelings to collectors was not unusual, but most of the recorded songs were not published in the Kanteletar, nor later in the series Suomen Kansan Vanhat Runot ('The Ancient Poems of the Finnish People', hereafter SKVR) because of the moral codes of publishing principles (see Timonen \& Kuusi 1997).

In the recorded lyric material, love songs represent longing for love, and more often longing for the lost love. There are also songs describing a young girl's hankering for proposals and for being desirable and popular among men (see, e.g., SKVR, Onpa tietty tietyssäni ('There is a certain one in my mind'), Tulepa yöllä yksinäsi ('Come alone by night')). However, more often songs describe a mutual emotion, and the feeling is melancholic rather than boisterous (see SKVR, Ei kuulu kullaistani ('My dear one is not heard'), Illan tullen ikävä ('Longing with night'), Kukku ennen mun käkeni ('My cuckoo used to cuckoo'), Kun ois kulta kuulemassa ('If my dear one was here to hear'), Missä lie minun omani ('Where is my own one')) (see Kuusi 1963: 403-404). The darling is described concretely through her or his presence in the daily life: love is combined activity in practical matters; the lover is the one who brings food, fulfils household tasks or warms up the bed. However, generally in discussing love songs, (male) scholars have not been interested in these songs, but rather take note of the song Jos mun tuttuni tulisi ('Should my treasure come'), which has been defined as representing an exceptional erotic passion of common people (Tarkiainen 1943: 42; Haavio 1952: 7). Even though sung as independent and fixed text, the song of Jos mun tuttuni tulisi is related to motifs and lines of other love songs, such as walking of the dear one and identification of the lover. The difference from other songs is found in the expression of strong erotic and bodily emotions.

Other than describing a feeling of love, lyric songs sung by women in Finland and Karelia relate to marriage, its demands, and frustrations. Getting married was of great importance in a woman's life. It presented her as a decent woman who, by giving birth, continued the family cycle. Remaining unmarried was not an option in rural culture; it could cause social and economic problems (Timonen 2004: 46; Apo 1989: 168). Thus, a feeling of love, even though naturally existing in rural culture in people's relationships, was not the main reason for getting married. Social demands and the objective of creating order within the family played a more important role. The songs reflected this social concern at the same time as they narrated individual feelings and experiences.

Within recorded folk poetry material, the song Armaan kulku is not a representative of the oral lyric poetry. Usually its main idea of the passage of the lover is combined with other love songs. According to the SKVR, 13 variants 
correlate with this specific poem, or its motif, of which only one was recorded before the Kanteletar was published in $1840 .{ }^{10}$ Generally the song describes a landscape through which the dear one has passed. In Ingria the poem is part of a longer lyric poem which represents a female subject describing her love (SKVR III 2 2424). One song is an incantation against a flea that destroys cabbage saplings ( $\mathrm{SKVR} \mathrm{XIII}_{3}$ 9910). One of the poems is probably adapted from a literary source (SKVR III $_{3}$ 2661). Lönnrot's contemporary, folk song collector D.E.D. Europaeus included Lönnrot's Armahan kulku in his folk-song anthology Pieni Runon-Seppä (1847). During his collecting journeys in Ingria, he distributed the book and the song became popular among common people. Three of the thirteen texts have sexual content (SKVR I $1987 ; \mathrm{V}_{2} 1075 ; \mathrm{XIII}_{2}$ 3167). The gender of the singer and the fictional subject vary. The singer is explicitly female in six texts $\left(\mathrm{SKVR} \mathrm{I}_{3} 1987 ; \mathrm{III}_{2} 2424 ; \mathrm{V}_{2} 1075 ; \mathrm{VI}_{2} 6539 ; \mathrm{XIII}_{3}\right.$ 9910; $\mathrm{XIII}_{4}$ 10803). In five texts it is possible to say that the singer describes her male lover (SKVR I $\mathrm{S}_{3}$ 1987; $\mathrm{III}_{2} 2424 ; \mathrm{III}_{3} 2661 ; \mathrm{V}_{2} 1075 ; \mathrm{XIII}_{2}$ 3167). It is difficult to say in four texts whether the description of the dear one is of a man or a woman (SKVR IV 1 1055; XIII 4 10803; VII 2 2358, 2393).

Similar to Lönnrot's version, many of the variants contain repetitive lines, such as armaan astunta ('walking of the dear one'), kivi paljon kirkkahampi ('the rock much brighter'), tuost on armas astunut ('this way the dear one has stepped'), tuost on kulta kulkenut ('here has the beloved gone') (SKVR III $_{2} 2424$; III $_{3}$ 2661; IV 1 1055; VI $6539 ;$ XIII $_{2}$ 3097, 3167; XIII 10803 , 10804, see also VII 2358). Discernible similarities of song variants to Lönnrot's own version raise a question of adaptation. Could we presume that the song Armahan kulku was created by Lönnrot, and then adapted to the oral tradition? The process might also have taken place the other way around. As the variants of Armaan kulku resemble the version of the Kanteletar, one might think that Lönnrot possibly had more texts than we are able to detect today. His sources might have got lost. Keeping these options in mind, I will next have a look at existing text variants, especially the ones that are different from Lönnrot's version.

One of the poems uses the same descriptions of the surrounding nature, but the message of the poem is of a bride longing for her childhood home, not for her darling. The recorded text is introduced with an explanation by the female singer:

Se ol' niinkun olis olt' morsian kun vietiin toiseen paikkaan, niin sillä ol' paha olla, sitte kun se tul' kotiin, niin se luki syntymä paikassaa että: It was as if it was the bride, when she was taken to the other place, yes, it was bad to be there, and then when she got back home, she enumerated in her birthplace how: 
Kivi on toistaan kirkkaampi, Paasi toista parempi, Lehti viittä lempeämpi, Kuusi kuutta parempi, Kangas --- olik' se seittentä kauniimpi, vai miten se ol'--(SKVR VI ${ }_{2} 6539,1-6$ )
The rock brighter than any other, The bolder better than others, The leaf five times softer, The fir-tree six times better, The heathland --- was it seven times more beautiful or, how was it ---

Lönnrot followed one song variant of Armaan kulku (the only one he had), which he had transcribed in southern Karelia (Karjalankannas) in 1837 (Kaukonen 1984: 228):

Täss' on kultani kulkenut, Täss on istunut kivellä;

Kivi on tullut kirjavaksi,

Paasi painunut pahaksi

Täst' on mennyt märkäkyrpä,

Kulkenut kusisaparo.

(SKVR XIII 2 3167, 1-6)
Here has my treasure walked, Here he/she has sat on a rock; The rock has become multicoloured, The boulder has sunk down, bad, Here has gone a wet cock, A pigtail of piss has walked.

The song starts with conventional lines: "Here has my treasure walked / Here he/she has sat on a rock", but then the poem moves on to a sexual and humorous image: "Here has gone a wet cock / A pigtail of piss has walked". Also the rock has become multicoloured and fallen, which may indicate that a sexual act took place on it. The singer uses sexual personification, making the lover (kulta) a sex organ. The "wet cock" could indicate that "my treasure" is he, and the song shows a woman longing for her love, or rather, making fun of it.

Compared to two other variants with the same sexual content (SKVR I I $_{3}$ 1987; $\mathrm{V}_{2}$ 1075), one may find that the song might have been sung with a naturalistic and humoristic rather than romantic view of love. Humoristic attitude and sexual personification are present in the recording of Lönnrot as well as in these later recordings. Both of the later texts are sung by women. Anni Lehtonen (in 1911) sung a seven-line song about a man called Matti, describing how Matti sniffs out the ground to be able to find a kusikki (indicates kusisaparo 'pigtail of piss') and Märkähini (indicates somebody wet) and pakkohini (SKVR I 1987; pakko literally means 'must do something', but can also mean a group of children, of cows, etc.; see KKSK 2009). Besides pakkohini, pakkohine is a common word in incantations referring to a person in pain or distress: Hätähisten huutaessa, pakkohisten parkuessa ('distress shouting, pain crying'; see SKVR I 1 298, 298a; 
$\mathrm{I}_{4} 285,548,959 ; \mathrm{VII}_{3} 358 ; \mathrm{XII}_{1}$ 4608). The song of Matti is considered as a play song in the SKVR. The translation of the line Sonni sompurah sijoja is not fully clear, but I have interpreted it as follows: Sonni (lit. 'a bull') is a synonym to a man, sompurah might indicate 'a hoof, a foot'. ${ }^{11}$
Matti maata nuhteloo,
Matti sniffs out the ground,
Sonni sompurah sijoja, The bull scrapes the place/ place for feet,
Täst' on kulkenu kusikki, This way has a pigtail of piss walked,
Täst' on männy Märkähini, Here has the wet one gone,
Pakkohini on paipatellun. Pakkohini has spoken loud.
Nyt on Matti maansa myönyn, Now has Matti sold his land,
Konna kaupinnun kotinsa.
The crook has peddled his home.
(SKVR I 1987)

The other poem sung by Anni Kurikka (in 1916) is located under "The song of boys singing about girls" in the SKVR. The song can be read as a dialogue between a girl and a boy. The girl speaks first ("here has the wet tail gone"), then the boy answers ("he has sprung along the swamp"). The girl's answer seems to be missing in the transcription, but the boy replies: "Here is the same wet tail, me sitting on this rock", and then he expresses his sexual intention:

Täst on männyt märkähäntä, This way has a wet tail gone,

Kulkenut kusisaparo,

Täss on istunut kivellä,

Kivi on tullut kirjavaksi.

Onpa juossut suota myöten

Sekä käynyt maata myöten.

Kuss'hia nytkii levännöö,

Miss hiä nytkii istunoo?

Istunooko kivellä?

Täss on sama märkähäntä,

Istun mie tässä kivellä

$---$

Kussa miun neitosein

Mitä minä rakastelisin

Jopa neitonen hävisi.

Minä etsin neitoani,

Kipps, kapps, hei!

(SKVR V 2 1075)
A pigtail of piss has walked,

Here he has sat on a rock,

The rock has become multicoloured.

He has sprung along the swamp

He has also gone on the ground.

Where is he now resting,

Where is he sitting at the moment?

Is he sitting on the rock?

Here is the same wet tail,

Me sitting on this rock

Where is my maiden

Who I would have sex with

The maiden has gone.

Me looking for my girl

Kipps, kapps, hi! 
This kind of dialogue sometimes occurs in dance and play songs in southern Karelia and Ingria. In these songs boys and girls are seeking their pairs (see SKVR XIII ${ }_{3}$ Piirileikkilauluja ('Ring game songs'), Etsi emäntiäsi, isäntiäsi ('Look for your mistresses, your masters'), Likat seisoo ringissä ('Girls standing in a ring'), Minä etsin neitoani ('I am looking for my maiden'), etc.). Ring and dance games were popular amusement among young people, for example, during long holidays. In these texts, one may think that they are connected to social situations where young people are teasing the opposite sex with sexual hints. Kaarle Krohn also noted this, saying that the song of Armaan kulku might have originally been sung as a play song (Krohn 1920: 51).

Worth mentioning here is that when editing the song for the lyric anthology, Lönnrot also had two other texts including similar lines of the walking of the dear one, even though they are not variants of Armaan kulku (SKVR VII 2 2344; $\mathrm{VII}_{5}$ 3390). A love poem of the cuckoo (Kukku ennen mun käkeni ('My cuckoo used to cuckoo')) includes a description of the loved one. The poem describes how the cuckoo has stopped singing, and the loved one is not seen passing through the alley anymore (SKVR VII 2 2344). Songs of the cuckoo predict the number of years a maiden has to wait until getting married. The cuckoo can also express a great sorrow (e.g. Aino's grief in the Kalevala by Lönnrot). In this poem example, the cuckoo reflects the lost love that used to call in the morning and evening, but now there is no sound of the lover. The song also carries a sexual implication. The dear one is called näätähattu, which is a metonym of a man who wears a hat of marten skin, but can also be an attribute of genitals and an expression of hunting for love in erotic songs and incantations (see Tarkka 2005: 269).

Vaanp ei kuulu kullastan[i],

Eip' oо ...

[there is something missing in the transcription]

Näy näätähattuistani

Kujosilla kulkevak[si],

Aitan viertä astumassa.

Muihen kulta kulkem[assa],

Muihen armas astumassa.

(SKVR VII 2 2344, 9-15)
There is no sound of my beloved, The dear one is not ...
My pine marten is not seen

Walking in the alleys, Stepping next to the fence.

The beloved of others walking, The dear one of others passing.

Another example is a recording of an incantation (boiling the skull of the bear) that includes several terms expressing affection for the bear as the dear one. The dear one is associated with a bear, who is enchanted to walk on a golden path, a silver road. The bear is called kulta, rahan armas ('golden darling, 
money-dear'), indicating the status of the bear as valuable game (SKVR VII 3390; Turunen 1981 [1979]: 25). In hunting rituals, the bear and the wedding are associated in order to create stability between social and physical borders. In the rituals, the bear is transferred into different roles, from game to a wanted bear, from a caught animal to the one who is returned to nature. The transmitting of roles implies changes in gender roles as well. Especially in the ritual of boiling the skull, the bear, now caught and undressed, ready to move back to the forest, is described with feminine hypocorism (Tarkka 2005: 272-275), as in the example text: Lähe nyt, kulta kulkemaan, I rahan armas, astumaan ('Go now and walk the dear one / money-dear be stepping') (SKVR VII 3390, 11-12). The sweetness (of the bear) and the erotic will as well as erotic tensions were emphasised in incantations, and, on the contrary, a parody of female and male genitals was expressed in many erotic songs (Tarkka 2005: 269).

\section{METADISCURSIVE PRACTICES}

Lönnrot had three different texts related to Armaan kulku, with the lover associated with erotic tensions, only one of which he edited for the Kanteletar. However, even though Lönnrot did not explicitly use the other songs (of the cuckoo and the incantation), they elucidate different options and motifs Lönnrot had in his editorial work of the song Armahan kulku. Besides, later recordings give an overall picture of the existing variants of Armaan kulku in the song tradition.

What did Lönnrot do to the oral song he followed in the Kanteletar? At first glance, even though the Kanteletar text is roughly Lönnrot's own combination, it looks like a pure oral lyric song, and this is how it has been interpreted. However, the difference from the oral song variant is explicit when these two texts are put side by side. Lönnrot interpolated the oral text, using various textual strategies. The version of the Kanteletar takes some lines of the poetic exemplar, but the concluding sexual lines are excluded. The rest of the poem is Lönnrot's own composition.

Täst' on kulta kulkenunna, Täss' kultani kulkenunna

Täst' on mennyt mielitietty,

Tästä armas astununna,

Valkia vaeltanunna;

Täss' on astunut aholla,

Tuoss' on istunut kivellä. 
Kivi on paljo kirkkahampi, Paasi toistansa parempi,

Kangas kahta kaunihimpi,

Lehto viittä leppiämpi,

Korpi kuutta kukkahampi,

Koko metsä mieluisampi,

Tuon on kultani kulusta,

Armahani astunnasta.

(Kanteletar I: 174, 1-14)
Kivi on tullut kirjavaksi, paasi painunut pahaksi, Täst' on mennyt märkäkyrpä, Kulkenut kusisaparo.

(SKVR XIII 2 3167)

This way my treasure has walked, Here my beloved has been, This way my dear one has stepped, And my white one has wandered; Here she has stepped in the glade, There she has sat on a rock.

The rock is much brighter, The rock has become multicoloured, The boulder better than the next, The boulder has sunk down, bad, Here has gone a wet cock, A pigtail of piss has walked.

The heath twice more fair,

And the grove five times sweeter,

The wild six times more flowery,

All the forest more pleasant,

Because that treasure of mine walked,

That dear one of mine stepped.

(Translation taken from Bosley 1990: 26-27)

As scholars have noted, the emotional feeling and message of the Kanteletar are contrary to the oral song (Kaukonen 1984: 29; Krohn 1920: 52). Lönnrot's version has a more positive and conventional tendency. The rock is brighter (it has not become coloured), the boulder better (not worse) from the passage of the beloved. Lönnrot's song also gives a general description of the treasured one. The person in the recorded oral text might be a woman who sings of sexual desire, or rather, of sexual laugh while personifying the 'love' as a sex organ. The person in the Kanteletar song is not explicitly either a woman or a man. The colour white, however, indicates a female in oral poetry, but other female 
symbols often presented in love songs, such as berry and bird, are not present in Lönnrot's song (Kuusi 1963: 404). In the last explanatory lines nature has become more feminine in response to the passage of the lover: more beautiful, milder, more flowery, and more congenial. However, Lönnrot did not clearly indicate the sex of the subject, nor of the love, but located the song in the group of Paimenlauluja ('Herdsman's songs'), which could be sung by both men and women.

In order to address a feeling in the song, Lönnrot used other textual and poetic strategies. Unlike in the oral text example, he used parallelism and repetitive, strong alliteration and assonance to establish the presence of the beloved: Täss' on kulta kulkenunna / Täss' mennyt mielitietty, / Tästä armas astununna, / Valkia vaeltanunna ('This way my treasure has walked / Here my beloved has been / This way my dear one has stepped / And my white one has wandered'). Nature is described through repetitive images and alliteration: Kangas kahta kaunihimpi, / Lehto viittä leppiämpi ('The heath twice more fair / And the grove five times sweeter'). To strengthen even more the importance of the sweetheart, the power of the lover's appearance, he used the comparative: Kivi on paljo kirkkahampi / Paasi toistansa parempi ('The rock is much brighter, the boulder better than the next'). In the folk exemplar the lover's power is related to a (negative) action and change: Kivi on tullut kirjavaksi, / paasi painunut pahaksi ('The rock has become multicoloured, / The boulder has sunk bad').

The beloved is called by several intimate attributes by Lönnrot. She is kulta ('golden', i.e. dear), mielitietty ('sweetheart'; also indicates desire), armas ('beloved'), and valkia ('white'). Lönnrot accumulated synonyms of the beloved that allude to the appearance of the dear one as well as the desire of the speaker. The words mielitietty and armas can connote somebody who is desirable (KKSK 2009; Turunen 1981 [1979]: 24). The word valkie is the colour white, but it also indicates purity and something beautiful (KKSK 2009). Lönnrot describes the look of the beloved as bright, good, pure, beautiful, and flowery through the images of nature whereas the oral song represents the lover in the opposite way. In the other recordings of the similar lines in the SKVR, more diverse features are attributed to the beloved. He or she can be described in terms of appearance: mustakulma ('black brow') (SKVR III 2 2424, III $_{3}$ 2661, $\mathrm{VII}_{2}$ 2358), hienohelma ('fine-hemmed') (SKVR XIII 10804); or sometimes in terms of natural entities: kuin puussa pähkinä ('like a nut in a tree'), mansikka mäellä ('strawberry on a hill') (SKVR III $2424 ;$ III $_{3}$ 2661; XIII $_{2}$ 3097), lillukka lehossa ('stone bramble in a grove') (SKVR XIII ${ }_{2} 3097$ ), oksalla omena ('apple on a branch') (SKVR III $2424, \mathrm{III}_{3}$ 2661). In some songs, the lover is also contrasted with an animal: 
orava ('squirrel') (SKVR XIII 2 3097) and näätähattu ('pine marten'; a man wearing a hat of marten skin) (SKVR VII 2 2344). Sometimes, but not very often, as compared to other love songs, the beloved is called by intimate attributes such as mielellinen, mielitietto, which indicate the desire and will of one's mind (SKVR XIII 2 3097; XIII 4 10803).

Oral songs describe love concretely. The idea of love is not only described as a tender sentiment between a man and a woman. Love is also represented as an affection toward the family or as an erotic tool for teasing between two sexes as it is expressed in dance and play songs. Besides describing longing, oral songs give several reasons for it: sorrow, sense of loss, erotic or humorous experience. Through meta-textual changes Lönnrot aspires to textual fidelity and stability (see Bauman \& Briggs 2003: 207), but also, in contrast to the oral song exemplar, a feeling more suitable for his readership, a feeling of vulnerable love. The feeling expressed in the song Armahan kulku is related to a sense of purity and longing. Lönnrot presents a feeling of love associated with nature. Even though the power of nature might also be linked to erotic experiences, for example, in incantations and sexual songs, Lönnrot does not indicate this side of nature in his version. Instead, he emphasises the importance of this feeling as well as its frequency, its naturalness for all people.

\section{INTERPRETATIONS}

In the analysis of the most widespread love song, Jos mun tuttuni tulisi, Seppo Knuuttila and Senni Timonen reflect whether all the collected variants of the song express the emotional language of the original singer (Knuuttila \& Timonen 1999: 195). One of the main problems in their article is elucidating the diverse emotional expressions and interpretations made of the song. While this poem has been regarded as a representation of love and passion between a man and a woman, several recorded versions of the poem show that the song describes rather a feeling of love and utopian relationship that could be sung not only about the other sex, but also, for example, about a mother. Also the fictional subject of the song has been seen to be a woman even though the song was sung by both sexes, and in many cases, the singer is unknown.

The feeling of love in the song by Lönnrot is related to an emotion of romantic love. Interpretations of the song Armahan kulku by folklorists and literary scholars have focused on the romantic relationship between a man and a woman. Most of them have considered the song as describing a man, the longed-for lover, fantasising about his love through the images of nature (Krohn 1920; 
Tarkiainen 1921; Kaukonen 1984; Bosley 1990). Moreover, the sexual content of the oral exemplar has been recognised but ignored. Finnish folklore scholar Kaarle Krohn noted Lönnrot's editorial technique in Armahan kulku, but did not point to folk examples behind the song, nor to their different emphases on the feeling of love. Instead, he reflected on the genre of the song. While admitting sexual lines in some oral texts, Krohn (1920: 51) argued that these lines might indicate that the song was sung as a leikkilaulu ('play song'), not as a song of love - as it was probably sung according to the text of Anni Lehtonen (SKVR I ${ }_{3}$ 1987). Literary scholar Viljo Tarkiainen recognised Lönnrot's own part in the composition, but instead of analysing Lönnrot's choice not to follow folk lyric tradition, he highlighted the content of the poem and its emotional space as a brilliant entranced vision with crystallised nature standing for the adulation of love (Tarkiainen 1921: 105-106).

Semiotician Pirjo Kukkonen regarded the song as telling about a girl singing of her lover. In her book about Swedish translations of the Kanteletar (2009), she elucidated the song Armahan kulku as a good example of Lönnrot's editorial methods of adding alliteration and parallelism more than there were in folk songs. Kukkonen stated that the poem of the Kanteletar describes a girl longing for her lover, and emphasised that by using strong alliteration and parallelism Lönnrot addressed the "girl's inside landscape when she sings of her lover's walking” (Kukkonen 2009: 92).

Some of the established views of folk lyric poetry were proposed by folklorists Matti Kuusi and Martti Haavio, who both tried to reconstruct folk songs into their original form. Matti Kuusi offered an oral text of Armaan kulku as an exemplar of the kind of love songs where daily routines and an instant erotic feeling are combined. Regarding the language and geographic distribution of the song, he found that the original singer was a woman from Savonia (a region in eastern Finland), who had a special ability to express a lyric moment as a here-and-now erotic experience (Kuusi 1963: 405). A reconstruction of the song by Kuusi is the following:

$\begin{array}{ll}\begin{array}{l}\text { Eipä kuulu kullaistani, } \\ \text { eipä liiku linnuistani, }\end{array} & \text { There is no sound of my beloved, } \\ \text { näy näätähattuani, } & \text { No move of my bird, } \\ \text { ei kuulu kujassa käyvän, } & \text { My pine marten is not seen, } \\ \text { alla ikkunan ajavan, } & \text { Not walking in the alley, } \\ \text { pilkkovan pinolla puita, } & \text { Going under the window, } \\ \text { kodan eessä kolkehtivan. } & \text { Chopping wood at the sheaf, } \\ \text { Täst on kulta kulkenunna, } & \text { Clattering in front of the hut. } \\ \end{array}$


täst on armas astununna, täss on istunut kivellä, täss on astunut aholla: kivi on muita kirkkahampi, aho on muita armahampi, paasi muita on parempi.
Here my beloved has gone, Here he has sat on a rock, There he has stepped in the glade: The rock is brighter than others, The glade more cherished than others, The boulder better than others.

According to Kuusi, this song is seen as representing one of the songs about longing for love, which reflects the fifteenth and sixteenth centuries' trends of transposing erotic and everyday expressions. However, in the SKVR, there is no such poem as Kuusi proposed, even though both sections of the song, Ei kuulu kullaistani ('There is no sound of my lover') and Täst on kulta kulkenunna ('This way my treasure has walked') are separately found in different love songs.

Martti Haavio reconstructed oral lyric songs in his book Laulupuu ('Tree of Song', 1952), aiming to normalise oral lyric songs into their 'original' folk lyric form, which he regarded as having been corrupted in Lönnrot's Kanteletar. In his preface he stated the idea of love represented by common people as follows: "Folk lyric poetry talks about love shyly and allusively, not saying the word that sleeps in the heart and intends to come into view" (Haavio 1952: 6-7). Even though the song is not a representative one for the oral lyric tradition, Haavio added a version of Armahan kulku to the group of love songs. Worth noticing in Haavio's text is its textual similarity to the oral variant (SKVR XIII 3167), but the feeling of love is equivalent to the song in the Kanteletar. The importance of the song emerges due to its placement in the anthology. Täst' on kulta kulkenunna ('This way the beloved has walked') starts a fifteen-song series of love songs (Haavio 1952: 67-74). The versions of Haavio and Lönnrot are as follows:

Tästä on kulta kulkenunna,

oma armas astununna,

tuoss' on istunut kivellä, tässä istunut aholla.

Kivi on tullut kirjavaksi, paasi on toistansa parempi,

korpi on kuutta kukkaisempi, lehto viittä leppeämpi. (Haavio 1952: 67)
Täst' on kulta kulkenunna, täst' on mennyt mielitietty, tästä armas astununna, valkia vaeltanunna; täss' on astunut aholla, tuoss' on istunut kivellä. Kivi on paljon kirkkahampi, paasi toistansa parempi, kangas kahta kaunihimpi, lehto viittä leppiämpi, korpi kuuta kukkahampi, koko metsä mieluisampi, 
tuon on kultani kulusta, armahani astunnasta. (Kanteletar I: 174)

This way my treasure has walked, My dear one has stepped, There she has sat on a rock, Here she has stepped in the glade, The rock has become multi-coloured, The boulder better than the next, The wild six times more flowery, The grove five times sweeter.

\section{LONGING FOR WHAT?}

The song in the Kanteletar has similarities to oral songs and their descriptions of love, but it has been modified to accord with readers' expectations and moral attitude. Lönnrot's ideological message of the song is included in the expression of emotion. The idea of love in a bourgeois context in the nineteenth century combined sensitive, romantic emotions, and the family as a moral entity (Giddens 1990: 37-38). However, a subjective feeling of love was secondary to the social feeling of the state of family. Hence, strong emotional expressions were not regarded as suitable among the middle class who aimed at self-control and regarded control of self-expression as an important principle to follow. The interpretations made of the song Armahan kulku have been based on the generic as well as cultural expectations of folk lyric and sentiments of love (e.g. DuBois 2006). I here turn to Seppo Knuuttila and Senni Timonen, and their analysis of the love song Jos mun tuttuni tulisi and its romantic and malecentred interpretation (Knuuttila \& Timonen 1999). The same interpretational obscurity can be seen in different readings of the song Armahan kulku. Despite the acknowledged fact that Armahan kulku did not exist as such in folk lyric poetry but was Lönnrot's own combination of lines, the song has been viewed as a beautiful folk song of love and has been included in selections from the Kanteletar. Sensuality and tenderness have been interpreted as describing the ideals of women even though the subject and the lover of the recorded texts could have been either a woman or a man. Nor have interpretations concentrated on the possible sexual or other motifs of the oral version of the song. Rather, sexual images have been ignored, and instead, interpretations have emphasised the descriptions of nature as correlating with female beauty. 
The written representation of the love song gives one interpretation, one image of love, while oral recordings carry diverse meanings. Recorded oral text variants in the SKVR reflect a more diverse feeling of love, with sexual, humoristic or mythic content, than the song of Armahan kulku in the Kanteletar. The idea of love is presented, though also in a romantic vein, as a complex, often erotic, experience that can reflect the feeling of love, which can be expressed in a humoristic sense, as a dialogue between young people dancing and playing, as a longing for something good, or, for example, in hunting rituals, as the power of nature and the bear, as well as of sexual appearance.

Further, if we look at all the recordings of Armaan kulku, we may reflect whether Lönnrot adapted the oral tradition and modified it according to his editorial purposes or whether the development occurred the other way around. As noted earlier, many of the recorded texts resemble Lönnrot's own version in the Kanteletar, and one of the recorded texts has explicitly been adapted from the Kanteletar (SKVR IV 1055 ) via a publication of D.E.D. Europaeus (1847). Therefore, it can be argued that text variants might have been learnt from the printed sources, then accepted and modified to the oral tradition (see also Krohn 1920: 51). In that case Lönnrot changed the tradition. Another option is that the lines of the beloved's walking come from the oral tradition; they were mainly sung in play songs by young people, but Lönnrot's sources are lost. In this case Lönnrot chose from different song line alternatives the one he personally liked and expected his bourgeois readers acknowledge it. By doing so, Lönnrot made the same personal choice oral singers have done before and after him. The difference from oral singers is found in Lönnrot's editorial purposes. He adapted, modified, and represented folk songs for publication.

Knowledge of the oral tradition is based on written presentations, and thus our understanding is a multi-layered interpretation. Recording and, particularly, publishing practices have made oral songs readable, but also reconstructed them ideologically and polished them to meet the expectations of contemporary readers. Lönnrot's textual strategies can be regarded as having a tendency to broaden or narrow the emotional message, to guide the meanings of emotional expressions, and, by doing so, to influence the views of the emotional behaviour of the common people. Furthermore, the reception and analysis of written representations of oral folk songs have extended or narrowed the original meanings and emotional messages as well.

The Kanteletar was viewed as a voucher for the beauty and sensibility of folk lyric. Beauty, purity, and vulnerable emotions were the ideals of the written culture, and those features were regarded as having been especially characteristic of the common people and their culture. Thus, the readers of the Kanteletar have tended to consider the songs and emotions as representations of the 
oral singing tradition through their own cultural expectations and knowledge. Armahan kulku is one of the exceptions in Lönnrot's editorial work because it has only a few similarities to the oral poetry. However, because of its nature as Lönnrot's own creation, it offers an interesting view of the tradition as multilayered cultural knowledge that is historically, ideologically, and emotionally constructed and represented for certain publishing purposes and audiences.

\section{ACKNOWLEDGEMENTS}

I am grateful to Clive Tolley for improving the language as well as for his critical comments.

\section{NOTES}

1 In some cases, the ideal of folk lyric as an expression of sorrowful emotions has occasionally been adapted by a folk singer regarding the taste and expectations of the elite audience. See, e.g., DuBois 2006: 203-211.

${ }^{2}$ On the reception of the Kanteletar see Gröndahl 1997: 31-35. Only few detailed studies have been published on the Kanteletar. Besides Väinö Kaukonen and his massive work in searching out the references of songs and lines Lönnrot used for the Kanteletar (1984), folklorist Satu Apo has written of the Kanteletar and its grotesque, naturalistic themes (1995a). See also Pertti Karkama's Kansakunnan asialla: Elias Lönnrot ja ajan aatteet (2001).

3 For example, the selected songs of the Kanteletar have been translated into 15 languages while the Kalevala has been translated into 60 languages.

4 On the textualisation practices of the Kalevala and the Kanteletar, see Hämäläinen 2014.

5 Herder defined the lyric as a shared language of a nation, its soul's grammar. Lyric was the most natural genre, common for all people and arising from its pure emotions (Herder 2000 [1795]: 27). Pertti Karkama emphasises that defining Lönnrot only through romantic ideas undermines his multifaceted thoughts and work (Karkama 2001: 172).

6 All the cited lines and lyric examples have been translated by the author.

7 Translation started already from the manuscript of the Kanteletar. Lönnrot himself made several translations of the songs and published them in Swedish periodicals between 1830 and 1840 (Anttila 1985 [1931]; Kukkonen 2009: 100).

8 See, e.g., Tiina Seppä, who has analysed this complex relationship between a collector and a singer in her dissertation published in 2015. See also Korhonen 2005: 60-61. 
9 Armahan kulku has been included in various selections of the Kanteletar songs: Suomen runotar (Lehtonen 1945 [1931]), Laulupuu (Haavio 1952), Itkivät ihanat nurmet (Jauhiainen 1990), Naurut naisten, mielet miesten (Koponen 2001).

${ }^{10}$ Variants of Armaan kulku (13) and the recording years: 1837: $\mathrm{XIII}_{2} 3167$ / 1845: $\mathrm{VI}_{2} 2358$ (incl. few lines, a part of the song Jos mun tuttuni tulisi) / 1854: $\mathrm{XIII}_{2} 3097$ (a part of the bigger poem) / 1859: $\mathrm{IV}_{1} 1055$ (Pieni Runon-Seppä)/ 1890: $\mathrm{VI}_{2} 6539$ / 1895: $\mathrm{VII}_{2} 2393$ / 1897: $\mathrm{III}_{2} 2424$ (a part of the bigger poem) / 1900: $\mathrm{III}_{3} 2661$ (/ 1911: $\mathrm{I}_{3} 1987$ / 1916: $\mathrm{V}_{2} 1075$ / 1935: XIII 9910 (incantation) / 1937: XIII 40803 , 10804. See also similar lines of the beloved one's walking in the following songs: $\mathrm{SKVR}_{2} 1154$; $\mathrm{V}_{3} 678 ; \mathrm{VI}_{1} 596 ; \mathrm{VII}_{2} 2344 ; \mathrm{VII}_{5} 3390$.

${ }^{11}$ E-mail conversation with Senni Timonen (4.3.2016 and 7.3.2016).

\section{REFERENCES}

Anttila, Aarne 1985 [1931]. Elias Lönnrot: Elämä ja toiminta. [Elias Lönnrot: Life and Work.] Suomalaisen Kirjallisuuden Seuran Toimituksia 417. Helsinki: Suomalaisen Kirjallisuuden Seura.

Apo, Satu 1989. Valitus ja viha: Lyyrinen laulurunous. [Moan and Hate: Lyric Song Poetry.] In: Marja-Liisa Nevala (ed.) "Sain roolin johon en mahdu": Suomalaisen naiskirjallisuuden linjoja. [I Got a Role I Did Not Fit In: Connections in the Finnish Women's Literature.] Helsinki: Otava, pp. 154-181.

Apo, Satu 1995a. "Hepo huono, akka tiine": Kanteletar realistisena kansankuvauksena. ["Bad Horse, Pregnant Crone": Kanteletar as a Realistic Description of People.] In: Satu Apo (comp.) Naisen väki: Tutkimuksia suomalaisten kansanomaisesta kulttuurista ja ajattelusta. [Woman's Strength: Research on Finnish Folk Culture and Thinking.] Helsinki: Hanki ja Jää, pp. 75-88.

Apo, Satu 1995b. Äidin poikia ja epäonnisia kosijoita: Sukupuolten ja perhesuhteiden kuvaus Kalevalassa. [Mother's Sons, Unlucky Wooers: Description of Gender and Family Relations in Kalevala.] In: Satu Apo (comp.) Naisen väki: Tutkimuksia suomalaisten kansanomaisesta kulttuurista ja ajattelusta. [Woman's Strength: Research on Finnish Folk Culture and Thinking.] Helsinki: Hanki ja Jää, pp. 89-129.

Bauman, Richard \& Briggs, Charles L. 2003. Voices of Modernity: Language Ideologies and the Politics of Inequality. Cambridge: Cambridge University Press.

Bendix, Regina 1997. In Search of Authenticity: The Formation of Folklore Studies. Madison, WI: The University of Wisconsin Press.

Bosley, Keith 1990. I Will Sing of What I Know: Fifty Lyrics, Ritual Songs and Ballads from the Kanteletar. Helsinki: Suomalaisen Kirjallisuuden Seura.

Briggs, Charles 1993. Metadiscursive Practices and Scholarly Authority in Folkloristics. Journal of American Folklore, Vol. 106, No. 422, pp. 387-434. DOI: 10.2307/541905.

Clifford, James \& Marcus, George E. (eds.) 1986. Writing Culture: The Poetics and Politics of Ethnography. Berkeley \& Los Angeles \& London: University of California Press. 
DuBois, Thomas A. 1994. An Ethnopoetic Approach to Finnish Folk Poetry: Arhippa Perttunen's Nativity. In: Anna-Leena Siikala \& Sinikka Vakimo (eds.) Songs Beyond the Kalevala: Transformations of Oral Poetry. Studia Fennica Folkloristica 2. Helsinki: Finnish Literature Society, pp. 138-179.

DuBois, Thomas A. 2006. Lyric, Meaning, and Audience in the Oral Tradition of Northern Europe. Notre Dame, IN: University of Notre Dame Press.

Enäjärvi-Haavio, Elsa 1935. Lyyrilliset laulut. [Lyrical Songs.] In: Martti Haavio (ed.) Suomalaisen muinaisrunouden maailma. [World of Finnish Ancient Poetry.] Porvoo: Werner Södeström Osakeyhtiö, pp. 112-175.

Europaeus, D. E. D. 1847. Pieni Runon-Seppä eli Kokous paraimmista Inkerinmaan puolelta kerätyistä runo-lauluista: ynnä Johdatuksia runon tekoon. [A Little Song of Smith, or a Collection of Folksongs Collected in Ingria, and Introduction to Poem Making.] Helsinki: Simeliuksen perilliset. Available at http://neba.finlit.fi/ kirjasto/digi/index.php?pagename=teokset-listset\&set=826\&item $=1$, last accessed on January 7, 2017.

Foley, John Miles 1991. Immanent Art: From Structure to Meaning in Traditional Oral Epic. Bloomington \& Indianapolis: Indiana University Press.

Giddens, Anthony 1990. The Consequences of Modernity. Cambridge: Polity Press.

Gröndahl, Satu M. 1997. Den ofullkomliga traditionen: Bilden av Ingermanlands kvinnliga runotraditionen. [Imperfect Tradition: Pictures of Women's Runo Tradition in Ingria.] Studia Uralica Upsaliensia 27. Uppsala: Acta Universitatis Upsaliensis.

Haavio, Martti (ed.) 1952. Laulupuu: Suomen kansan tunnelmarunoutta. [Tree of Song: Lyrical Poetry of Finnish People.] Porvoo \& Helsinki: Werner Södeström Osakeyhtiö.

Hämäläinen, Niina 2014. Why Is Aino not Described as a Black Maiden? Reflections on the Textual Presentations by Elias Lönnrot in the Kalevala and the Kanteletar. Journal of Finnish Studies, Vol. 18, No. 1, pp. 91-129.

Herder, J[ohan] G[ottfried] 2000[1795]. Lyyra: Lyyrisen runotaiteen luonteesta ja vaikutuksesta. [Lyre: On the Nature and Impact of Lyrical Poem Art.] Translated by Vesa Oittinen. In: Tuula Hökkä (ed.) Oi runous: Romantiikan ja modernismin runouskäsityksiä. [Oh Poetry: Conceptions of Poetry in Romanticism and Modernism.] Suomalaisen Kirjallisuuden Seuran Toimituksia 786. Helsinki: Suomalaisen Kirjallisuuden Seura, pp. 22-28.

Jauhiainen, Marjatta (ed.) 1990. Itkivät ihanat nurmet: Valikoima Kantelettaren runoja. [Sweet Greens Crying: A Selection of Kanteletar Songs.] Suomalaisen Kirjallisuuden Seuran Toimituksia 516. Helsinki: Suomalaisen Kirjallisuuden Seura.

Karkama, Pertti 2001. Kansakunnan asialla: Elias Lönnrot ja ajan aatteet. [Working with the Concern for the Nation: Elias Lönnrot and Ideologies of Time.] Suomalaisen Kirjallisuuden Seuran Toimituksia 843. Helsinki: Suomalaisen Kirjallisuuden Seura.

Kaukonen, Väinö 1956. Elias Lönnrotin Kalevalan toinen painos. [Second Edition of the Kalevala by Elias Lönnrot.] Suomalaisen Kirjallisuuden Seuran Toimituksia 247. Helsinki: Suomalaisen Kirjallisuuden Seura. 
Kaukonen, Väinö 1984. Elias Lönnrotin Kanteletar. [The Kanteletar of Elias Lönnrot.] Suomalaisen Kirjallisuuden Seuran Toimituksia 386. Helsinki: Suomalaisen Kirjallisuuden Seura.

Kaukonen, Väinö 1989. Lönnrot ja Kanteletar. [Lönnrot and Kanteletar.] Suomalaisen Kirjallisuuden Seuran Toimituksia 507. Helsinki: Suomalaisen Kirjallisuuden Seura.

KKSK 2009 = Karjalan kielen sanakirja. [Dictionary of the Karelian Language.] Kotimaisten kielten tutkimuskeskuksen verkkojulkaisuja 18. Available at http:// kaino.kotus.fi/cgi-bin/kks/kks_etusivu.cgi, last accessed on January 9, 2017.

Knuuttila, Seppo \& Timonen, Senni 1999. Jos mun tuttuni tulisi: kansanrunon modaaliset kontekstit ja ruumiilliset tunteet. [If My Treasure Would Come: Modal Contexts and Bodily Emotions of Folk Poetry.] In: Sari Näre (ed.) Tunteiden sosiologiaa I: Elämyksiä ja läheisyyttä. [Sociology of Emotions I: Experiences and Intimacies.] Tietolipas 156. Helsinki: Suomalaisen Kirjallisuuden Seura, pp. 195-228.

Koponen, Anneli (ed.) 2001. Naurut naisten, mielet miesten: Kantelettaren säkeitä elämän arkeen ja juhlaan. [Women's Laughs, Men's Minds: Verses of the Kanteletar for Days and Feasts in Life.]. Helsinki: Gummerus.

Korhonen, Anu 2005 [2002]. Constructing Emotion in a Culture of Hierarchies: A Love Story. In: Anu Korhonen \& Kirsi Tuohela (eds.) Time Frames: Negotiating Cultural History. Cultural History / Kulttuurihistoria 1. Turku: Kulttuurihistorian laitos, Turun yliopisto, pp. 57-73. Available at http://www. doria.fi/handle/10024/117973?show=full, last accessed on January 9, 2017.

Krohn, Kaarle 1920. Kantelettaren runojen kokoonpanosta. [On the Composition of the Songs in the Kanteletar.] Suomalainen Suomi, Vol. 5, pp. 43-54.

Krohn, Kaarle 1931. Tunnelmarunojen tutkimuksia I: Laulusta. [Studies of Lyrical Poetry I: On Singing.] Helsinki: Suomalaisen Kirjallisuuden Seura.

Kukkonen, Pirjo 2009. Det sjungande jaget: Att översätta känslan och själen. Den lyriska samlingen Kanteletar $i$ svenska tolkningar 1830-1989. [The Singing Self: To Translate Emotion and Soul. The Lyrical Collection Kanteletar in Swedish Translations.] Acta Semiotica Fennica XXXI. Helsingfors: Semiotiska sällskapet i Finland.

Kuusi, Matti 1963. Myöhäiskalevalainen runous. [Late Kalevalaic Poetry.] In: Matti Kuusi (ed.) Suomen kirjallisuus I: Kirjoittamaton kirjallisuus. [Finnish Literature I: Unwritten Literature.] Helsinki: Suomalaisen Kirjallisuuden Seura \& Otava, pp. 398-417.

Kuutma, Kristin 2006. Collaborative Representations: Interpreting the Creation of a Sámi Ethnography and a Seto Epic. FFC 289. Helsinki: Academia Scientiarum Fennica.

Laitinen, Heikki 2003. Surullista, köyhää ja nöyrää. [Sorrowful, Poor and Meek.] In: Hannu Tolvanen \& Riitta-Liisa Joutsenlahti \& Heikki Laitinen (eds.) Iski sieluihin salama: kirjoituksia musiikista. [Lightning Hit My Soul: Writings on Music.] Suomalaisen Kirjallisuuden Seuran Toimituksia 942, Kansanmusiikkiinstituutin julkaisuja 55. Helsinki: Suomalaisen Kirjallisuuden Seura, pp. 189-197. 
Lehtonen, Johannes Vihtori (ed.) 1945 [1931]. Suomen runotar: Valikoima suomalaista runoutta koteja ja kouluja varten. [Finnish Muse: Selection of Finnish Poetry for Families and Schools.] Porvoo \& Helsinki: WSOY.

Lönnrot, Elias 1838. Finska Runor. [Finnish Poems.] Borgå Tidning, No. 58, July 25. Available at http://digi.kansalliskirjasto.fi/sanomalehti/binding/389867, last accessed on January 9, 2017.

Lönnrot, Elias 1990. Valitut teokset 2: Mehiläinen. [Selected Works 2: Mehiläinen.] Ed. by Raija Majamaa. Suomalaisen Kirjallisuuden Seuran Toimituksia 531. Helsinki: Suomalaisen Kirjallisuuden Seura.

Lönnrot, Elias 1993. Valitut teokset 5: Muinaisrunoutta. [Selected Works 5: Ancient Poetry.] Ed. by Raija Majamaa. Suomalaisen Kirjallisuuden Seuran Toimituksia 580. Helsinki: Suomalaisen Kirjallisuuden Seura.

Lönnrot, Elias 2000 [1840]. Kanteletar elikkä Suomen kansan vanhoja lauluja ja virsiä. [Kanteletar, or Old Songs and Hymns of Finnish People.] Helsinki: Suomalaisen Kirjallisuuden Seura.

Lutz, Catherine \& White, Geoffrey M. 1986. The Anthropology of Emotions. Annual Review of Anthropology, Vol. 15, No. 1, pp. 405-436. http://dx.doi.org/10.1146/ annurev.an.15.100186.002201.

Salminen, Väinö 1945. Etelä-Karjalan runonlaulajat ja tietäjät. [Runo-Singers and Seers of Southern Karelia.] In: Väinö Salminen (ed.) Suomen Kansan Vanhat Runot XIII: Etelä-Karjalan runot, Vol. 4. [Ancient Poems of Finnish People XIII: Songs of Southern Karelia.] Helsinki: Suomalaisen Kirjallisuuden Seura, pp. 577-595.

Seppä, Tiina 2015. Kohtaamisia menneen kanssa: Tutkimus kansanrunoaineistojen synnystä ja myöhemmistä tulkinnoista. [Encounters with the Past: A Study of the Construction of Folk Poetry Sources and Their Interpretations.] Kultaneito XVI. Joensuu: Suomen Kansantietouden Tutkijain Seura.

SKVR = Suomen Kansan Vanhat Runot. [Ancient Poems of Finnish People.] Available at www.skvr.fi, last accessed on January 9, 2017.

Tarkiainen, Viljo 1921. Viisi Kantelettaren runoa. [Five Poems of the Kanteletar.] Kalevalaseuran Vuosikirja, Vol. 1, pp. 100-112.

Tarkiainen, Viljo 1943. Tunnelmarunous. [Lyrical Poetry.] In: Viljo Tarkiainen \& Hertta Harmas (eds.) Suomen kansalliskirjallisuus III. [Finnish National Literature.] Helsinki: Otava, pp. 242-257.

Tarkka, Lotte 2005. Rajarahvaan laulu: Tutkimus Vuokkiniemen kalevalamittaisesta runokulttuurista 1821-1921. [Songs of the Border People: Kalevala-Metre Poetry in Vuokkiniemi Parish in 1821-1921.] Suomalaisen Kirjallisuuden Seuran Toimituksia 1033. Helsinki: Suomalaisen Kirjallisuuden Seura.

Timonen, Senni 2004. Minä, tila, tunne: Näkökulmia kalevalamittaiseen kansanlyriikkaan. [Self, Space, and Emotion: Aspects of Kalevala-Metre Folk Lyric.] Suomalaisen Kirjallisuuden Seuran Toimituksia 963. Helsinki: Suomalaisen Kirjallisuuden Seura. 
Timonen, Senni \& Kuusi, Matti 1997. Alkusanat. [Preface.] In: Matti Kuusi \& Senni Timonen (eds.) Suomen Kansan Vanhat Runot XV: Runoja Henrik Florinuksen, Kristfrid Gananderin, Elias Lönnrotin ja Volmari Porkan kokoelmista. [Ancient Poems of Finnish People XV: Poems from the Collections of Henrik Florinus, Kristfrid Ganander, Elias Lönnrot and Volmari Porkka.] Suomalaisen Kirjallisuuden Seuran Toimituksia 685. Helsinki: Suomalaisen Kirjallisuuden Seura, pp. XXV-XL.

Turunen, Aimo 1981 [1979]. Kalevalan sanat ja niiden taustat. [Words of the Kalevala and Their Backgrounds.] Lappeenranta: Karjalaisen Kulttuurin Edistämissäätiö.

Niina Hämäläinen is a post-doctoral researcher in folkloristics at the Research Unit of the Finnish Literature Society in Helsinki, Finland.

niina.hamalainen@finlit.fi 